\title{
“There is No Hiding from the Self:" A Conversation with Isabel Quintero
}

\author{
RODRIGO JOSEPH RODRIGUEZ \\ The University of Texas at El Paso
}

Isabel Quintero, author of the young adult novel Gabi, a Girl in Pieces, shares her writing life and commitment to readers of all ages and backgrounds through inclusive literature. Moreover, she advances the conversation by speaking about the adolescent characters in her work, specifically the characters' quest to name themselves and their identities in the presence of competing forces, influences, and voices.

In an empowering sense of self and purpose, the poet Pablo Neruda observes, "In my poems I could not shut my door to the street" (54). This perspective is just as relevant between writer and teacher in the choice and decision to write, think, and teach in the profession, while maintaining an open exchange of ideas among teachers, school leaders, students, and authors. The act of making teaching, thinking, and learning visible can transform the profession and the lives of our students and colleagues by creating a more caring, just world in our practice and what we advance as professionals and artists.

So too does Paulo Freire remind us about intellectual discipline and cultural work that involves teachers and students: "There is no discipline in immobility, in indifferent, distant authority that immobilizes freedom, in the authority that dismisses itself in the name of respect for freedom" (87). How can the writer and the teacher form the bonds of empowerment and resistance in their practices? Isabel Quintero, author of the young adult novel Gabi, a Girl in Pieces, reveals in this conversation the influences for her writing life and ways to offer more voices and perspectives to adolescent worlds that resist conformity for compliance's sake. Moreover, the characters she introduces make adolescent lives visible to reimagine the "youth lens as a [social] construct" in our teaching, reading, and everyday lives (Sarigiandes, Lewis, and Petrone, 16). 
The conversation was conducted during a period of struggle in classrooms, ranging from resistance to mandated and new assessments as well as challenges to prescribed instruction to making school culture and learning more relevant, just, and accessible for students of all abilities, backgrounds, colors, and interests.

Isabel was born and raised in southern California, an area she describes as "desert, winds, warehouses, citrus, and freeways." Her parents were born in México: her father was born near Culiacán, Sinaloa, while her mother was born in Tarimoro, Guanajuato. Isabel's love of reading and writing began with her mother reading to her during the evenings and later from the teachers and professors who encouraged her to continue writing and pursuing her craft.

One of Isabel's fondest memories involves walking to the public library with her mother and brother, carrying too many books home. Isabel recalls, "My mom always helped me with the load. She was always encouraging when it came to school and reading. I remember learning how to read, and she would sit and read Amelia Bedelia to me." Isabel has worked in public schools as a teacher, substitute teacher, and elementary school library technician. She has also worked as an adjunct professor at Mt. San Jacinto Community College.

Isabel is the 2015 winner of the William C. Morris Award from the Young Adult Library Services Association (American Library Association), which honors a book written for young adults by a previously unpublished author. She still lives in Southern California. The conversation began in early Fall 2015, via email correspondence and telephone, and was completed in Spring 2016.

Joseph: It is wonderful to have the opportunity to have a conversation about your writing and life, Isabel. Tell us about your adolescence.

Isabel: Seeing how that was only a couple years ago, this should be easy. Ha! I was a teenager in the 1990s, that time period just before cell phones and computers completely changed our way of communicating with each other. I attended Santiago High School, a mostly White, upper middleclass, upper-class high school where many of the students drove better cars than the teachers. I was an outsider on many fronts. For instance, my parents were working-class Mexican immigrants, and therefore I couldn't afford the snowboarding/surfing/camping trips many of my peers could. I was light-skinned, but still not White. I liked school, and it came easily, especially English. However, I was lazy and distracted, and therefore my grades were often mediocre. I loved having friends, but 
never felt like I fit in with them. Not that I thought I was better. I just didn't party or drink or dateactivities usually associated with typical American adolescence. My mother was very strict, and so I was afraid of consequences if I were caught doing something like drinking. No, she didn't hit me, but I was always still afraid; and too, I always felt less than. I also had a lot of issues going on at home that made it difficult to concentrate on anything besides reading, my main escape.

During those years I had terrible self-esteem, I was a fat girl who didn't think any boy would be interested and so, if a boy was interested, I quickly found ways to push him away in fear of it being a joke or wondering what the hell was wrong with him that he'd even look at me that way. I look back now and realize: 1) I wasn't fat, and 2) I had a lot to offer. But those feelings were very hard to deal with, and I found refuge in the library. How cliché, right? But I did. I read a lot and, after learning about e.e. cummings in tenth grade, I began writing terrible poetry.

Because I came from a low-income home and had been taught that if you want something you work for it, I worked during my junior and senior year. During my junior year, I did a stint at McDonald's, but my whole senior year was spent as a teacher's aide at a private preschool and daycare. I was also very involved with my Roman Catholic Church youth group during this time, and while I am not very religious now, it really helped me cope with the loss of my abuelito, who died my senior year in 1999.

It wasn't all hard though. I had friends, and we had sleepovers. We went to quinceañeras, danced (with a tía and primo as chaperone, of course), skated on a first date, went to prom (twice), and tagged along with my friends who had money to go on trips. With my family, we went to México a couple times to visit familia and, when times were good, we went out to dinner and we'd travel to Las Vegas or visit family friends in the Central Valley or my tia in Van Nuys. While it wasn't until college that I really began to really understand how marginalization worked, I participated in the Hispanic Women's Club and Spanish Club, both safe spaces to let the Latina part of myself free. Adolescence was a wonderful time, and also an anxiety-ridden hellhole, but I think that is true for many teens.

Joseph: Share what you recall about your sense of imagination and creativity growing up and through young adulthood that influences your writing for children and young adults.

Isabel: I have always had a wild imagination. When I was a kid, I would always go to my Nina’s [godmother's house]. She had nine children, some of whom are only a few years older than me. This meant that I grew up learning English about the same time I was learning Spanish. Also, the 
older kids, who were very bossy, had a wild imagination, and therefore we played in the world that they created and that world became our world. One of our favorite games was "Run Away from the Orphanage," in which we, the orphans, would go on daring adventures during our escape from Ms. Hannigan. Often no one played Ms. Hannigan, but she was always with us nonetheless.

Even when I wasn't with my godbrothers and godsisters, I would play house or with my Barbies by myself. When he was old enough, my brother, who is almost seven years younger, would be forced to participate in Christmas musicals or play office or school.

Using my imagination, much like writing later, gave me an ability to control the world around me and let me live somewhere else for a moment. This has influenced my writing in many ways, especially because writing often requires, at least for me, that we live somewhere else for a moment-whether a world we have created or a world we are reinterpreting. So many times during the writing of Gabi, I had to get into the persona of the characters and really be there in order for it to be realistic.

While writing for children, I think about the books that really influenced me as a child and now as an adult. As a child, I would get lost in story without thinking of craft. As an adult, I get lost in story and then look at how the story was crafted that allowed me to get lost so easily within it. When I read Jarrett Kroskca, Yuyi Morales, Juan Felipe Herrera, Duncan Tonantiuh, Jon Klassen, or even Mo Willems, I am in awe of how effortless they make picture books seem. Picture books are not effortless; in fact, they are a lot of work and a lot of thought, care, and craft goes into creating one. I am partial to picture books that are funny or thought-provoking. For $\boldsymbol{U} g l y$ Cat and Pablo, a chapter book which comes out in 2017, I was influenced by some of those authors who just made me laugh out loud. When I worked as an elementary school library technician, I found that the books that really made kids want to read more were books that made them laugh, and I decided I wanted to do that-make kids laugh.

For young adults, my influences are similar. I think sometimes the young adult label dissuades readers from opening up a YA book. Many people think that YA is about teen girls who are obsessed and willing to die for sparkly vampires, but there is much more than that. In fact, there are similar books in "mainstream" fiction. I say this because I used to think the same thing, until I read Fat Kid Rules the World by K.L. Going, Speak by Laurie Halse Anderson, and crashboomlove by Juan Felipe Herrera. It was a "holy shit" moment. I started reading YA and children's books with a different lens, and this actually got me started on Gabi. 
Joseph: Your novel Gabi, a Girl in Pieces has two subtitles with strikethrough: A Gordita and A Fatgirl. My students were immediately drawn to the cover, even though they speak with a voice of scolding, "We mustn't judge a book by its cover, Doc!" The pieces become a whole of a young person shaping herself into who she wishes to become. You explained to Daryl Grabarek in an interview that Gabi resembles you some in bravery and experiences.

Isabel: Well, she resembles how brave I wish I had been. Gabi admits, albeit mostly to herself, how she feels about sex and wanting to know what it's like to be with a boy, and even makes the first move when she is confronted with the opportunity. It wasn't until college that I realized that they were normal feelings for a girl to have. We are taught that it is normal for boys/men to think about and want to have sex, but that girls/women who do are "sluts" and I believed it. I wanted to look back and think about how it would have been if I had been brave enough/confident enough to believe that a boy would be interested in me or that I could leave home for college.

The biggest obstacle for Gabi is realizing that she is fragmented, because she is trying to conform to everyone else's (family/friends/culture/boyfriends) expectations of who she should be and that the only way to become whole is to listen to herself and walk her own path. Sometimes that path will align with her mom's and sometimes it won't-but that's okay because that is life.

The book is not an autobiography. Yes, Gabi and I are fat, light-skinned, Mexican American girls, who have a bit of anxiety and love to write. Some of the characters are based on real folks but they are ALL amalgamations of several people at once-even Gabi. We are not one and the same. What I found, as I got older, is that I was not as alone as I thought I was. There were many other teens that had gone through the same family life, same questions, fighting the same gender expectations, and getting in trouble for it as I did. I found that my experiences were not unique and that made me think there were probably other teens out there, right now, who needed to be reminded of that.

Joseph: Written as an epistolary novel, young adult readers describe how the opening grips them by the throat. They dive in as Gabi confesses albeit loudly, "My mother named me Gabriela after my grandmother who-coincidentally-didn't want to meet me when I was born because my mother was not married and was therefore living in sin" (7). They explain that a grandmother not wanting to meet her granddaughter makes them want to know more and what else gets turned upside down as either a sin or virtue. 
Isabel: I hadn't read that first entry as taking on sin and virtue. We see this with Tía Bertha, who has no trouble ascribing sin and virtue to people's behavior, but the reality is much more complicated. Sin and virtue are ideas that are attached to religion, and are often used to keep women in check. While men are expected to be virtuous, there are leniencies when they falter. Unless, like Sebastian, you are gay, then off with your head. For instance, saying, "She is good because she takes care of her child" and "She is bad because she is having sex before marriage," makes judgment so simple. Easy.

But it also creates a false dichotomy, which forces both the judge and judged to adhere to stringent, unrealistic guidelines that only take into consideration one particular set of dogmatic rules. If we are guided by these simplistic notions of what is good and what is not, we not only run the risk of being hypocritical and self-righteous, but also run the risk of feeling horrible shame and failure when we do not meet these unrealistic expectations. These are not constructed with human nature and kindness in mind, but instead with fear and control. Ultimately, Tía Bertha and Gabi's mother, are afraid of what hell will be unleashed if Gabi creates her own rules.

Joseph: In Disabling Characters: Representations of Disability in Young Adult Literature, Patricia A. Dunn reminds us, "[T]he status quo is not acceptable. All sorts of barriers prevent people from living their lives to the fullest, including how forces in society make them feel about themselves" (1). For Gabi and those with whom she lives, studies, and comes of age, the forces come toward her in both relentless and self-affirming ways.

Isabel: Yeah, they do! But it's life. For people of color, and other marginalized people, we often have to construct or reconstruct the world around us. In Borderlands/La Frontera: The New Mestiza, Gloria Anzaldúa writes,

So don't give me your tenets and your laws. Don't give me your lukewarm gods. What I want is an accounting with all three cultures-white, Mexican, Indian. I want freedom to carve and chisel my own face, to staunch the bleeding with ashes, to fashion my own gods out of entrails. And if going home is denied me then I will have to stand and claim my space, making a new culture-una cultura mestiza-with my own lumber, my own bricks and mortar and my? own feminist architecture. (44)

Of course, she is speaking on being Mestiza, but this idea, of constructing the self, has always stayed with me: of having the power to create ourselves, even after being torn apart. It's not all 
negative though. Gabi and her friends are able to start chiseling a space for themselves, and they learn the importance of culture, community, and familia.

Joseph: We learn about Gabi’s parents, her brother Beto, and her best friends Sebastian and Cindy and their struggles as Gabi comes to her own. Their models and the motives of others are questioned and even dissected to make a new life that sometimes means not following social mores and family rules. Likewise Sean P. Connors and Ryan M. Rish observe,

[C]ompeting cultural models produce disagreements about how marriage is defined, how masculinity and femininity ought to be performed, and which immigrants are welcome in the United States. When this is the case, dominant cultural models that are informed by systematic inequities privilege some groups of people at the expense of others. (24)

Your narrative turns these perspectives upside down with possibilities to be human and free from judgment under society's watch.

Isabel: Those power structures that make Gabi and her friends and family feel less than are neither new nor recent. Sometimes they are only visible to them; not because the power structures (oppression/racism/sexism/religious extremism) don't exist, but because they are made to look at and experience them every day, while others in their same society are not.

Joseph: Gabi endures the misconceptions about who she can be and become as she explains Tía Bertha's way of seeing Gabi's world: "She says that a nice young woman does not expose her thoughts like that [in a poetry reading] to the public. That writing is something that only men should do, like going to college. She still hasn't wrapped her head around the fact that I am going to college (I hope)” (131-132). Moreover, Tía Bertha shares “man-getting-advice” with her niece. The reader faces Gabi's dilemmas to become her own person despite a scripted, pre-arranged narrative for her life.

Isabel: Going against what family expects of us is especially difficult and painful. The fear for Gabi and for many, especially women, is that we are being disloyal, and that makes us bad. Obviously, this is not true, though it's sometimes hard to believe that it isn't. Again, this is where and how those invisible power structures clench their fists around our hands and try to lead us away from ourselves.

Joseph: Gabi writes to name her realities and thus survives through writing-albeit a challenge. By penning her thoughts, however, she names herself and those who listen to her words. Cherríe Moraga explains, "I experience myself writing beneath the suffocation of a blanket of isolation and 
censorship" (5). Is this the story of Gabi, young adults, and writers who struggle to name themselves?

Isabel: Yes. I think many of us, young and old, struggle with the labels and categories we are asked to exist in. They are often uncomfortable and ill-fitting. What happens when we have been named by others our whole lives or we have only been allowed to see pieces of ourselves in school? Consider curricula and literature that exclude people of color, persons with disabilities, gender-nonconforming individuals, and (gasp!) atheists. By being omitted, we are encouraged to see those pieces of ourselves as less than and it takes relearning (something I still struggle with) for us to be able to name ourselves, or even wanting to name ourselves. It is a painful process.

Writing gives me an opportunity to sort out my thoughts and try and find myself. I actually have to look at the words I use to interpret the world. There is no hiding from the self there. And that's a good thing.

Joseph: Gabi becomes an every female for the reader, yet she maintains her unique identities and personality as she defines herself in the presence others. These qualities connect with female and male readers who can relate to and understand the internal and external conflicts Gabi faces based on ethnic and family cultures, which too often establish ways of seeing and being. Antero Garcia asks, "[I]f YA books are directed toward building culture for the readers that encounter them, exactly whose culture are we talking about?” (6).

Isabel: I am not sure I can really answer that because culture is not stagnant; it is, like language, fluid and ever-changing. Even within a same country culture is diverse. There are, however, unifying threads like language, religion, and gender roles. But maybe more than just building culture, we writers of color and other marginalized groups are creating artifacts for ourselves, as proof of our existence for us, and in doing so, we validate ourselves. This of course is problematic, though not in the sense that it is not necessary. On the contrary, it is crucial that we do this, and it is a responsibility to our communities. However, because as a writer, to be published in the traditional way, I need to have the approval of a publisher, and often because there is a limited outlook on how a particular group of people should write in publishing (agents, editors, book designers), there are expectations on how our voices should sound and be used.

Writers whose voice deviates from those expectations sometimes get silenced. There are many steps before the reader actually gets the book. I've been on panels where authors have shared book covers being White-washed, because covers with people of color are harder to sell. So 
whose culture? It's all of the cultures that we are a part of, especially if we've been censored in the hopes of being more palatable or marketable.

Joseph: Gabi explains, "Having a father who is addicted to meth is exhausting. It's like you have to walk on eggshells all the time. Have to be scared all the time. And definitely have to be anxious all the time" (37). Describe how you came to understand and write Gabi's adolescent life and even her father's own coming of age.

Isabel: Real life experiences and research.

Joseph: Adolescent ways of speaking without restraint come alive in your narrative. Would you say that you're "dismantling stereotypes" through language and dialogue as your characters speak and rename what family is and values?

Isabel: I hope so. There is no one way to be a family, just as there is no one way to be Mexican or Mexican American, or poor, or woman. It's interesting that you should say, "without restraint" when it's restraint that Gabi is constantly fighting against, because restraint is one of the things that would make her a good girl.

Joseph: In the Los Angeles Times Festival of Books session titled "Through a Different Lens: YA Fiction Conversation,” you explain the need for not only human diversity, but also inclusivity. You added, "When we use the word diverse, the question then becomes, 'What are we diverting from?"' Tell us more about this perspective of both diversity and inclusivity, which offers more lenses for us as readers of your writing and young adult literature for all youth.

Isabel: I have no problem with the term diverse on its own. The word simply means variety, and that is something publishing desperately needs. For instance, I go into Barnes \& Noble, and I look for books by award winning authors: Yuyi Morales, Duncan Tununtiuh, Carmen Tafolla, or Juan Felipe Herrera, Benjamin Alire Saenz, and nada. None of them is on the shelves; they need to be special-ordered. Or I look for new books by writers of color that have been getting much acclaim and nada.

I guess my aversion to the use of the word applied to marginalized authors is that it allows for tokenism, such as: "Come meet our diverse authors!" "This month's diverse featured authors!" The default is still White, cis, able-bodied, and heterosexual. When we say diverse, it still puts those authors at the center of the literary universe and other voices are just different-exotic. Because White authors are at the center, they are allowed or asked to speak on topics like craft, 
genre, character development, setting, dialogue or any other topic not specifically labeled diverse whereas "diverse" authors are asked to speak on diversity.

I think that diversity can be addressed by marginalized authors in ALL conversations about the writing process and literature, perhaps not in the way that is expected, but it will be addressed because those experiences and realities inform our writing. Those conversations should be had with all authors, diverse or not, out of respect.

The use of inclusive instead of diverse actually came from YA author Jason Reynolds during a panel at the Tucson Festival of Books in 2015. I like that word, though it has its own problems. Ultimately, I have trouble with labels that are ascribed by others, because they come with expectations. Whatever the case, whatever the term, change needs to happen. Indeed, we need more diverse books, because readers are diverse and need to see themselves on a page; not because they are a separate entity from the default, but because this is the reality we live in. There should be no default. The world is diverse, and it's time our bookshelves reflect this reality.

Joseph: The poems, music, and telenovelas, soap operas, sequenced in your novel connect us to the characters in varied voices we hear, experience, and see struggling in their bodies and in the presences of others who either love or harm them, or both. Also, the excerpt from the zine, which Gabi created and titled "THE FEMALE BODY," appears with seven diagrams as graphic innovations (194-202).

Isabel: Right, I mean, that's all part of the fragmentation of the self. All of those things show characters a part of themselves or, at least, a part of the expectations society or family has for them in terms of behavior or how they should see themselves. The poetry especially teaches Gabi a lot about using words to question expectations and to construct her own set of values and own set of expectations.

Joseph: Overall, the young adult novel is reimagined with new forms of expression that resonate with diverse youth lenses. What led you to including graphic art within your novel with some essential realizations about coming of age?

Isabel: I started making that zine before I wrote the book, and I didn't know what to do with it. When I began rewriting the book, it just felt natural that Gabi would make one and it pushed me to finish it. I think because Gabi is determined to be a writer, the zine offers an immediate way of putting her words in as many people's hands as possible, and in that process she becomes 
empowered because her voice, her questions and anger with female expectations, goes beyond her journal and her classroom.

Joseph: Elizabeth Johnson insists, "Nowhere is the power of conceptions of adolescence more visible than in how we feel, think, and act when young people perform their sexual identities. Sexuality makes visible the intricate web of social, institutional conceptions that circulate what it means to be youthful” (62). By questioning these conceptions, does Gabi become our hero by gaining her own sense of self?

Isabel: I think readers can make that judgment. Though, I don't think Gabi is so different from many young women I know and grew up with.

Joseph: Susan L. Groenke and others argue, “[W]hen youth of color 'resist' or 'rebel against' the status quo in our outside of school, they become criminals-'public enemies,' 'menaces to society.' Similarly, youth of color don't have 'normal' curiosities about sex or natural sex drives; instead they are 'hypersexual,' oversexed, their desires base and carnal” (36). As a committed writer, how do you maintain connected to adolescent life and experience?

Isabel: Groenke makes an excellent observation, one which I have to agree with. I am an adjunct professor at a community college, so I am always around young people in the last few years of their teens. Also, I have a lot of nieces and nephews.

Joseph: Ms. Abernard's big heart for Gabi and belief in her writing resonates for so many of us in literacy education. Patricia Sánchez acknowledges that we live and teach in a "highly stratified society" and that "we cannot forget our own dignity is interdependent with the dignity of othersand such interdependence is inextricably bound to how we dignify our students in our classrooms every day” (369). Tell us about these teachers who are in the arts and you include in your writing.

Isabel: Ms. Abernard is a mix of a bunch of teachers who inspired me or encouraged me to write and to teach. As a teacher, I think we are in a position to help guide our students. I remember a professor in a credential class once said something along the lines of, "Whatever you say or don't say to a student affects every day," and I believed it. The arts are often seen as luxuries, hobbies that people take up for fun. In reality, the arts are a necessity for culture and society to understand itself. It's a way of looking outward and inward simultaneously as well as creating change.

For instance, think about all the poetry, visual art, and performing arts of the last few years during the Ferguson and Baltimore uprising; think about Claudia Rankine's Citizen, think Poets Responding to SB 1070, think all the guerrilla performances in Mexico after the disappearance of 
the 43 students from Ayotzinapa Rural Teachers' College. A lot of these artists are students and a lot of them are teachers. Art can be seen as an extension of the classroom or at least a response to what's happening or not happening in the classroom.

Let's remember that not all classrooms are in an institution and not all teachers have credentials or graduate degrees. For example, my mother was an excellent teacher and so were my grandmothers, but so were my college professors, like Drs. Jackie Rhodes, Julie Paegle, and Ellen Gil-Gomez-all amazing women and teachers.

Joseph: Thank you for sharing your writing with us as well as your perspectives that open many doors for our readers and teachers.

Isabel: It has been a pleasure, Joseph. Thank you, and thank you for reading.

\section{REFERENCES}

Anzaldúa, G. (1987/2012) Borderlands / La frontera: The new mestiza. 1987. San Francisco: Aunt Lute Books.

Connors, S. P., \& Rish, R. M. (2015). Troubling ideologies: Creating opportunities for students to interrogate cultural models in YA literature. The ALAN Review, 42(3),22-34.

Dunn, P. A. (2015). Disabling characters: Representations of disability in young adult literature. New York: Peter Lang.

Freire, P. (1998). Teachers as cultural workers: Letters to those who dare teach. Trans. Donaldo Macedo, Dale Koike, and Alexandre Oliveira. Boulder, CO: Westview Press. Garcia, A. (2013). Critical foundations in young adult literature: Challenging genres. Rotterdam, The Netherlands: Sense Publishers.

Grabarek, D. (2014). Constructing a life: A conversation with Isabel Quintero. School Library Journal, 12 Aug. 2014.

Groenke, S. L., Haddix, M., Glenn, W. J., Kirkland, D. E., Price-Dennis, D. \& Coleman-King, C. (2015). Disrupting and dismantling the dominant vision of youth of color. English Journal 104(3), 35-40.

Hartzler, A. (2015). “Through a Different Lens: YA Fiction Conversation, @ LA Times Festival of Books [with Isabel Quintero, et al.].” Online video clip. YouTube. YouTube, 16 May 2015. 
Johnson, E. (2015). Sex in the English classroom: Text, counter text, and social text. English Journal 104(3), 61-67.

Moraga, C. L. (2011). A Xicana codex of changing consciousness: Writings, 2000-2010. Durham, NC: Duke University Press.

Neruda, P. (1977). Memoirs. Trans. Hardie St. Martin. New York: Farrar, Straus and Giroux.

"Pick Up The Pieces With ‘Gabi,’[by Meg Medina].” (2014). Weekend Read. NPR.

Quintero, I. (2014). Gabi, a Girl in Pieces. El Paso, TX: Cinco Puntos Press.

Sánchez, P. (2015). Dignifying every day: Policies and practices that impact immigrant students. Language Arts 91(5), 363-371.

Sarigiandes, S. T., Lewis, M. A., \& Petrone, R. (2015). How re-thinking adolescence helps reimagine the teaching of English.” English Journal 104(3), 13-18.

\section{BOOKS BY ISABEL QUINTERO}

Quintero, I. (forthcoming 2014). Gabi, a Girl in Pieces. El Paso, TX: Cinco Puntos Press.

-. Ugly Cat and Pablo. (2017). New York: Scholastic.

Read more about Isabel Quintero on her webpage http://www.laisabelquintero.com or follow her on Twitter@isabelinpieces.

RODRIGO JOSEPH RODRIGUEZ is an assistant professor of Literacy and English Education at the University of Texas at El Paso. He can be reached via email rjrodriguez6@utep.edu or catch him virtually on Twitter @escribescribe. 